\title{
The Effect of Organizational Culture and Work Motivation on Employee Performance: The Mediating Role of Job Satisfaction
}

\author{
Endang Saefuddin Mubarok \\ Faculty of Economics, Jakarta Islamic University, Jakarta, Indonesia
}

\begin{abstract}
This research aimed at understanding the effect of organizational culture and work motivation on job satisfaction and its impact on the performance of PPSU employees in the Semper Barat Area, DKI Jakarta. The path analysis with descriptively and explanatorily-quantitative method was used for this research. The samples were 60 respondents by using sampling method. The results of this research indicated that organizational culture and work motivation significantly affected the work satisfaction. Similarly, organizational culture and work motivation had a directly significant effect on employee performance. Job satisfaction had a significant effect on employee performance. In addition, work satisfaction was able to significantly mediate the indirect effect of organizational culture and work motivation on employee performance.
\end{abstract}

Keywords: Organizational culture, work motivation, job satisfaction, and employees' performance

DOI: $10.7176 / \mathrm{EJBM} / 11-35-09$

Publication date: December $31^{\text {st }} 2019$

\section{Introduction}

Rapid and complex global changes are driving various conflicts in organizations. From time to time, competition is getting tougher that every organization competes to be superior. A competition will only be won by those who have high competitiveness. Competitiveness is defined as the ability to compete in speed and innovation (Bahaudin, 2000), so that (Guerra, 2008) the generations living in the global era are required to have superior performance. An organization's competitiveness can only be achieved by having quality human resources. Building quality human resources is not an easy job, compared to building technology.

Today, the problem faced by every organization is how to continuously improve the knowledge of the human resources. Therefore, the efforts of improving the knowledge as a learning process becomes crucial for having excellent human resources. Meaning, the efforts of making the learning process as a part of work behavior are necessary (Bahaudin, 2000). The parameters that can be used to assess the learning process, whether the human resources have competitiveness or not (Kasali, 2010), are those who are not only well educated, relevant to brain memory formed due to obtaining knowledge, but also those who are trained (cultivated), relevant to muscle memory formed by doing exercise.

Work is an activity and it constitutes a part of human life for changing their situation to be better. The change is aimed at meeting the needs, maintaining life and surviving. By working and obtaining experiences, someone will gain progress in his/her life. During the working process everyone can see how his performance is. Performance is basically the success level of an individual or group of the overall implementation of the task during a certain period compared with predetermined criteria (Mubarok, 2017). Therefore, organizations building excellent competitiveness through their employees will be able to manage the behavior and results of all employees. The achievement of human resource performance is influenced by internal and external factors. Every employee has the ability based on knowledge, skills, competencies that are appropriate to his/her job, personality, attitude, behavior, leadership, organizational culture, motivation, and satisfaction in working.

The ability to do things differently in accordance with the local culture is necessary. However, it does not mean that one should freeze the original attitude to subsequently forms a new attitude permanently (Lewin, 1947). Managers working with diverse cultural backgrounds require high flexibility and adaptability. In the expanding business world, we will not only be exposed to the same culture, but to various cultures. On the extent of increasingly widespread and rapid change, managers are required to manage people in a variety of cultural diversity. The implication is that managers not only face work challenges in cultural diversity, but also have to guide their teams and people in varied conditions.

For those involved in planning and implementing a performance management process, motivation is an important factor. According to Vroom (1964), a person's performance is a result of his level of ability and level of motivation. The performance management process is relevant to intrinsically motivate people by carrying out performance appraisal, training and development and goal setting (Rees and McBrain, 2007). The results of management are the real rewards relevant to intrinsic motivation. If someone craves something, it means he has an expectation that as a consequence, he is motivated to take an action for achieving it (Colquitt et al., 2012). If the expectation is met, then satisfaction is felt associated with performance, job satisfaction does not necessarily affect work performance (Dessler, 2013). However, there is often a positive correlation between high job satisfaction and high work performance. An organization is founded with a specific purpose, which is something 
that is expected to achieve. To ensure that the expected results can be achieved, the implementation of organizational activities should be managed properly. This research aimed at making the efforts to analyze and collect data and information relevant to organizational culture, work motivation, and job satisfaction affecting the employee performance.

\section{Literature Reviews}

\subsection{Organizational Culture}

Organizational culture is a system of shared meanings held by its members distinguishing the organization from other organizations (Robbins, 2005), as the product of all organizational characteristics, its members' characteristics as well as their success and failure. (Werther et al., 1996). Organizational culture is a set of values and norms that guide the behavior of the line of the organization (Luthans, 2007), which consists of shared values and assumptions within the organization (Glinow et al., 2007), able to be seen from the ideal form/idea, behavior, and physical form (Koetjaraningrat, 1982). Based on the four views above, it can be formulated that organizational culture is the belief, values and norms widely held in shaping and giving meaning to employees so that they become habits, which are reflected in idea, behavior, and physical forms.

For companies, organizational culture functions (Kreitner and Kinicki, 2007): (1) to provide organizational identity to employees; (2) to provide collective commitment; (3) to promote social system stability; and (4) to form behaviors by helping the managers feel their existence. According to Susanto (1997), organizational culture functions as (1) the role in carrying out tasks in the field of human resources; and (2) a reference in preparing the companies' plans. According to Ouchi (1982), corporate culture serves to teach its members how they should communicate and relate in solving problems. Chatab (2007) has the opinion that organizational culture functions as: (1) Organizational identity; (2) Social cohesion; (3) Inspiration resources; (4) Driving sources and behavior patterns; (5) Ability to increase added value; (6) Substitute for formalization; (7) Mechanisms of adaptation to change; and (8) context orientation. From the four views above, it can be formulated that the functions of organizational cultures are basically as a reference in shaping behavior, increasing human resource competence, inspiration source, and increasing competitive value that ultimately they affect the effectiveness of organizational performance.

There are some approaches in determining the effectiveness of satisfying performance (Chatab, 2007): (1) Goal attainment approach; the effectiveness of the organization should be assessed in relation to the achievement of objectives rather than the means; (2) System approach; the organization receives input, carries out the transformation process, and produces output; (3) Strategic constituencies approach; fulfilling the demands of constituencies in the organizational environment that support the sustainability of the organization; and (4) Competitive values approach; identifying all main variables contained in effectiveness area and subsequently determining how these variables are interconnected.

In an organization, it can be distinguished between strong and weak organizational cultures. A strong organizational culture is characterized by core values that are strongly held, well regulated, and widely shared. The more accepted the core values are, agreeing on the level of importance and feeling very attached to it, the stronger the culture is. Young organizations have weak organizational cultures, because their members do not have the same understanding and shared experience. But it does not mean that all mature organizations with stable members have a strong culture.

A person's success depends greatly on how that person thinks, especially about strategic resources sourced from ideas and information that come out of our minds. Human behavior and the changes (Chatab, 2007), are formed by a combination of cognitive aspect (related to thinking), psychomotor aspect (related to actions) and affective aspect (related to attitudes) as well as influenced by other basic characteristics. These three aspects are known as KSA factors (Knowledge, Skill, Attitude). In terms of interacting skill, every human or individual can be classified according to ability: (1) Interpersonal skill; interpersonal interaction skill; and (2) interpersonal skill; the deepest interaction skill in every human being.

Building a company that has a strong culture is a major management challenge in various companies. Therefore, it is necessary to hold special training and development programs to help employees in reach the right level of competence (Rees and McBrain, 2007). A collection of skills and competencies across all layers of the company, transformation of structures, processes and procedures, as well as a change in mindset from a single culture to a diverse culture into a marker of a culturally-fluent company. The cultural fluency training and development program includes: (1) Strategically cultural fluency; relating to the cross-cultural strategic relationship, international business development, mergers and acquisitions, partnerships and partnerships; (2) Work group cultural fluency; relating to the ability to lead multicultural teams and international projects; and (3) Personally cultural fluency; knowledge and skills relevant to work relations and social ethics.

The process of organizational culture change will be not easy since it is difficult to know about what is being discussed and what is being focused on. There is no general perspective available which helps the process of cultural change to begin. However, there are some experts' views on the dimensions in building an 
organizational culture. According to Robbins (2005), dimensions of organizational culture include: (1) Innovation and risk taking; (2) Attention detail; (3) Outcome orientation; (4) People orientation; (5) Team orientation; (6) Aggressiveness; and (7) Stability. While according to Moeljono in Chatab (2007), the dimensions of organizational culture consist of: (1) Integrity; (2) Professionalism; (3) Role Models; and (4) Respect for human resources.

Cameron et al. (1999) divides the organizational culture dimension into two-first dimension and the second dimension. The first dimension differentiates the effectiveness criteria emphasizing flexibility, flexibility and dynamics from the effectiveness criteria emphasizing stability, order and control. The second dimension differentiates the effectiveness criteria emphasizing the internal orientation, integration and unity from the effectiveness criteria emphasizing external orientation, differentiation and competition. The correlation between organizational culture and the effectiveness of organizational performance is determined by the combination of values and beliefs, rules and practices, and the correlation between the two (Denison, 1990 in Hartijasti, 2001). Organizational experts and researchers acknowledge that organizational culture has a significant effect on organizational performance and long-term effectiveness (Sedarmayanti, 2017).

The results of Kotter and Heskett's (1997) study concluded the correlation between organizational culture and company performance: (1) Corporate culture has a significant effect on long-term economic performance; (2) Organizational culture becomes an important factor in determining the success or failure of a company; (3) Culture that encourages inappropriate behavior and impedes the choice of the right strategy, slowly emerges when the company has good performing; and (4) Although difficult to change, a corporate culture can be built with the purpose of improving the performance.

\subsection{Work Motivation}

Motivation is basically a force driving individuals to take or not to take an action, existing internally or externally, positively or negatively to lead them achieving the goals. Motivation represents the psychological process encouraging someone taking an action in the form of attitude and behavior. Work motivation cannot be measured directly, but people can come to a conclusion by observing the attitudes and behaviors that are visible and demonstrated by the employees in carrying out their works. In view of the complexity of motivation, there is no single answer to the question about what is the motivation of employees to work well. Nevertheless, there are several main theories able to be used in relation to performance management (Rees and McBrain, 2007), viz.: (1) Extrinsic motivation; associated with the appreciation put into reality; (2) Intrinsic motivation; relevant to psychological appreciation; (3) Content theory; showing that someone acts to meet his/her needs; and (4) Process theory; relating to the conscious aspects of motivation; about how behavior is moved, directed, and maintained.

Although experts define motivation in different expressions, but their definitions are substantially the same, i.e., to express the power that drives someone to take action for achieving his/her goals. Kreitner and Knicki (2001) define motivation as the process of encouraging and directing behavior towards goal achievement. Meaning, if a manager wants to succeed in guiding the workers in achieving the company's goals, it is important to understand this psychological process. While according to Robbins (2003), motivation is a process resulting in intensity, direction, and ongoing efforts of individuals towards the achievement of goals. Persistence (intensity) means how long does a person keep trying; direction means what people do; and efforts means how hard people try to continuously realize a good performance.

Motivation is also defined as a series of processes encouraging, directing, and maintaining human behavior towards the goal achievement (Greenberg and Baron, 2003). Motivation refers to the reasons underlying behavior (Guay et al., 2010), and the reasons for doing something (Armstrong, 2009). Thus, motivation means arousing the relevant driving power or energy behind the action. Motivation is also relevant to choice people make and the direction of their behaviors. Motivated individuals will carry out their duties for a long time to achieve their goals. The reason humans do things is because in their lives they have many needs that must be met. Abraham Maslom formulated a need with five stages-psychological, security, social, appreciation, and selfactualization needs (Mubarok, 2017). The managerial implication of Maslow's theory indicated that a need satisfied might eliminate its motivational potential. Therefore, managers should be able to motivate their employees through the programs they need.

Performance problems arise if a person's work behavior is below what is expected and the problem is not due to low motivation, but it is because of communication, ability/ skill, training, and opportunity problems. In connection with that matter, there are several ways that organizations need to do in building motivation (Wibowo, 2016): (1) Assessing attitudes; (2) Becoming a good manager; (3) Improving communication; (4) Creating a culture of 'not blaming each other'; (5) Winning cooperation; and (6) Encouraging initiative. In fact, motivation can spur employees to work hard so that they can achieve their goals and increase their productivity and consequently affecting the achievement of organizational goals. Motivation can be sourced (Sedarmayanti, 2017), from: (1) The possibility of developing; (2) Type of work; and (3) The pride of employees being part of the organization where they work. 


\subsection{Job satisfaction}

Job satisfaction shows how people feel the work based on various aspects. The reasons why companies should pay attention to job satisfaction are: (1) Humans have the right to be treated fairly and respectfully; and (2) Job satisfaction can create behaviors affecting the company's functions. Job satisfaction is important for individuals at work. The level of job satisfaction gives will impact differently the organization. High job satisfaction encourages the realization of organizational goals effectively, on the contrary, low job satisfaction, sooner or later, brings setbacks to the organization (Byars \& Rue, 2008). Job satisfaction is a general attitude of an individual towards his/her job (Robbins, 2006), and positive or negative attitudes of an individual in performing his/her job (Greenberg and Baron, 2003). Meanwhile Gibson et al. (2000) has the opinion that job satisfaction is the attitude of workers towards their job. The attitude is the result of their perception on the job.

Job satisfaction is a collection of feelings, beliefs, and thoughts about how a person responds to his job (George and Jones, 2007 in Priansa, 2016), and is an affective or emotional response to various aspects of their job (Kreitner and Kinicki, 2007). In line with this, according to Megginson et al. (1982), people experience job satisfaction when they feel good about their job and that feeling often arise from achievements and recognition after the job is well performed. Since job satisfaction is influenced by employees' emotion and feelings, it has a major influence on various aspects of life (Sempane et al., 2002). The definitions indicate that job satisfaction is not a single concept. Meaning, a person can be relatively satisfied with one aspect of work and not satisfied with one or more other aspects. The employees' satisfaction or dissatisfaction feeling for their job reflects their attitudes and behavior when working. According to Keitner and Kinicki (2007), in an organization an individual's job satisfaction is determined by: (1) Need fulfillment; the characteristics of the job provide opportunities to meet an individual's needs; (2) Discrepancies; shows the difference between expectations and what are received; (3) Value attainment; the job provides important work value for individuals; (4) Equity, fair treatment at work; and (5) Dispositional/generic component; Job satisfaction is partly a function of personal traits and generic factors towards the work environment.

The correlation between job satisfaction and other aspects could be strong or weak. A strong correlation indicates that managers can significantly influence other variables by improving the job satisfaction (Kreitner and Kinicki, 2007). According to Gibson et al. (2000), there is a reciprocal relationship between performance and job satisfaction. On the one hand, job satisfaction causes performance improvements so that satisfied workers will be more productive. On the other hand, job satisfaction can occur due to performance so that productive workers will get satisfaction. The emergence of this reciprocal relationship indicates the absence of a specific direction or relationship between job satisfaction and performance. Vecchio (1995) had the opinion that performance indirectly caused job satisfaction. Performance would be rewarded, both intrinsically and extrinsically, while job satisfaction was obtained based on the employee's assessment towards the reward received. If workers felt that giving awards was fair, it would increase the job satisfaction. However, on the contrary, it would cause dissatisfaction. One of theories explaining job satisfaction is the Motivator-Hygiene (M$\mathrm{H})$ theory developed by Fredrick Herzberg. This theory leads to job satisfaction and HR turnover and between job satisfaction and HR commitment. Substantially, M-H theory disagrees about high service fee, because high service fee is only able to eliminate job dissatisfaction, but is unable to bring job satisfaction (Soedarmayanati, 2017). To bring job satisfaction, Herzberg suggests companies to do job enrichment, viz. the efforts to create jobs with greater challenges, responsibilities and autonomy.

\subsection{Employee Performance}

Today, performance and importance value are included in all aspects of modern life. In corporate life, performance touches every aspect of business administration that consequently, all management will strengthen it (Corvellec, 1997). Therefore, performance becomes a measure of life or death of the company. Organizational experts differ in defining performance. Gomez-Mejia et al. (1987) defines performance as a combination of financial success (the company) and the extent to which the company could prosper its stakeholders. On the other hand, Mayer and Zucker (1989) defines company performance as a function of achieving goals or targets. Other experts define performance as follows. Performance is the result of work that is closely related to organizational and consumer goals, and contributes to the economy (Armstrong \& Baron, 2009), showing a record of the results of the operation of functions for a certain time (Bernarddin and Russel, 2003), by acting properly according to company's background (Corvellec, 2001), which results can be measured (Whitmore, 1997 in Subari, 2014), compared with the targets set (Cushway, 2002), from what employees do and do not do (Mathis and Jackson, 2004). In other words, performance shows the process of doing correctly a job needed and the results achieved from what is carried out, and how to do it within a certain period of time.

Performance is basically about achieving difficult goals, as well as how to deliver measurable performance. Thus, a framework of two categories arises which accommodates what and how the performance is (Rees ang McBrain, 2007), viz.: (1) Difficult targets that will form the basis of the company's evaluation by external parties; and (2) Achievement of values and behaviors that are declared important by the company internally. Good 
performance management benefits employees and organizations (Ruky, 2009 in Idris, 2014) since it will: (1) increase the achievements; (2) encourage productivity; (3) develop personality; (4) become the basic development and training programs; (4) become the basis for determining compensation; and (6) enable the employees to express their feelings. In government sector, performance management is important because it is triggered by a government modernization agenda that emphasizes results and measures of success in performance. In private sector, the importance of performance management is due to its attention to shareholder value. In carrying out the performance management, there are three dimensions serving as factors that influence performance (Robbins, 2003)-ability, motivation, and opportunity.

The principles in preparing a good performance management program (Wibowo, 2008) are, among others: (1) strategic planning; (2) measurement implementation; (3) continuous improvement in performance; (4) development (5) work culture establishment; and (6) consensus, cooperation and two-way communication. According to Kreitner and Kinicki (2007), good performance management is supported by two things: (1) Ability of potential and reality; and (2) work motivation. To find out early on whether or not deviations occur from the plan, the implementation of the plan needs to be monitored and controlled. Therefore, feedback from the implementation process becomes very important so that it can correct deviations and organizational goals can be realized. There are two functions of feedback (Chang, 2008): (1) Instructional function; clarifying the role or teaching new behaviors; and (2) motivational functions; giving or promising rewards. According to Campel (1990), the measuring parameter of individual performance when evaluated practically include: (1) The fulfillment of sufficient specific and non-specific tasks; (2) Oral and written communication skills; (3) Showing the efforts; (4) Maintaining self-discipline; (5) Maintaining management performance; and (6) Management and administration. The measurement of performance at the department and work center level includes: (1) The quality of works; (2) Quantity of results achieved; (3) Time to reach the target; and (4) Cost efficiency of result achievement (Lynch \& Kelvin in Kreitner, 2007).

\section{Methodology}

3.1 Research Hypotheses

One of the factors affecting job satisfaction was organizational culture as stated by Ouchi (1982), Kreitner \& Kinicki (2007), Kotter \& Heesket, 1997, and Sedarmayanti, 2017. It was also supported by the results of the studies carried out by Ilham (2018), Nair \& Sommerville (2017), Zhang \& Li (2013), Soetikno (2017), and Susetyo and Darmanto (2015). Based on the thoughts and results of the study above, the first hypothesis was formulated as follows:

Hypothesis 1: Organizational culture significantly affected job satisfaction.

Work motivation was one of the factors that influence job satisfaction as stated by Rees \& McBrain (2007), Robbins (2003), and Greenberg \& Baron (2003). It was also supported by the results of studies by Kadir and Mamalia (2017), Langi et al. (2015), Bajpai and Rajpol (2018), Sohail et al. (2014), Saleem et al. (2010), Cong and Van (2013), and Ali et al. (2016). Based on the thoughts and results of the studies above, the second hypothesis was formulated as follows:

Hypothesis 2: Work motivation significantly affected job satisfaction.

One of the factors affecting job satisfaction was organizational culture as stated by Ouchi (1982), Kreitner \& Kinicki (2007), Kotter \& Heesket, 1997, and Sedarmayanti, 2017. It is also supported by the results of the studies carried out by Davoodalmousavi (2013), Mappamiring (20015), Bangun et al. (2018), Purnama (2013), Kamau and Waryoike (2019), Widyaningrum (2011), Ahamed and Mahmood (2015). Based on the thoughts and results of the studies above, the third hypothesis can be formulated as follows:

Hypothesis 3: Organizational culture significantly affects employee performance.

Work motivation is one of the factors that influence employee performance as stated by Rees \& McBrain (2007), Robbins (2003), and Greenberg \& Baron (2003). It is also supported by the results of studies by Langi et al. (2015), Mappamiring (2012), Bangun et al. (2018), Ali et al. (2016), Mubarok and Putra (2018), Cong and Van (2013) and Widyaningrung (2011). Based on the thoughts and results of the studies above, the fourth hypothesis can be formulated as follows:

Hypothesis 4: Work motivation significantly affects employee performance.

Job satisfaction is one of the factors that influence employee performance as stated by Byars and Rue (2008), Kreitner and Kinicki (2007), and Gibson et al. (2000). It is also supported by the results of the studies carried out by Bangun et al. (2018), Langi et al. (2015), Syauta et al. (2012), Miah, Md Murad (2018), Davoodalmousavi (2013), Kamau and Wanyoike (2019), Purnma (2013), Ahamed and Mahmood (2015). Based on the thoughts and results of the study above, the fifth hypothesis can be formulated as follows:

Hypothesis 5: Job satisfaction significantly affects employee performance.

While the sixth and seventh hypotheses proposed in this research can be formulated as follows:

Hypothesis 6: Organizational culture mediated by job satisfaction affects employee performance

Hypothesis 7: Work motivation mediated by job satisfaction affects significantly the employee performance 


\subsection{Research model}

The method used for this study was causality, and non-probability sampling and purposive sampling were used as the data collection methods. The data source in this study was primary data collected using questionnaire instruments. The respondents of this study were the employees of PPSU in Semper Barat Area, DKI Jakarta. By using Slovin method, the number of samples in this study was 60 respondents of 148 employees with a confidence level of 0.95 . The data analysis model in this study used path diagrams in the form of regression equations as follows.

Equation 1:

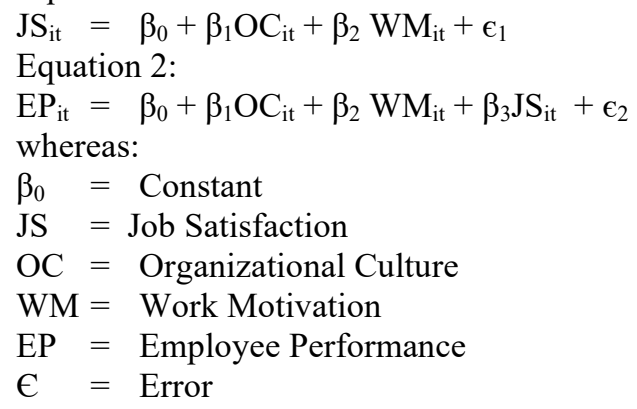

\section{Results and Discussions}

\subsection{Hypothesis testing}

The independent variable of both organizational culture and work motivation had a significant effect on job satisfaction. Simultaneously, the two independent variables significantly influenced the job satisfaction variable. The job satisfaction model showed good result since the R-Square value was 0.897 . Meaning, the variation proportion of job satisfaction variable explained by the independent variables was $89.7 \%$ and the remaining was explained by other independent variables. Table 1 below was an estimation of variable data regression influencing the job satisfaction.

\begin{tabular}{|c|c|c|c|}
\hline No. & Variables & Coefficient & $\mathrm{p}$-value \\
\hline 1 & Constant & -6.424 & $0.025^{*}$ \\
\hline 2 & Organizational Culture (OC) & 0.400 & 0.000 \\
\hline 3 & Work Motivation (WM) & 0.586 & 0.000 \\
\hline
\end{tabular}

* Significant on level 5\%

From the output of data processing, the value of the $\mathrm{p}$-value variable obtained was 0.000 . Therefore, there was at least one variable that was not 0 , it could be concluded that simultaneously, the independent variables influenced the job satisfaction variable customer. Based on the data of table 3 above, an equation could be made as follows:

$$
\text { Job Satisfaction (JS) }=-6,424+0.585 \mathrm{OC}+0.891 \mathrm{WM}+0.321
$$

The independent variables of organizational culture and job satisfaction had a significant effect on employee performance. Simultaneously, the three independent variables significantly influenced the employee performance. The employee performance model could be said not too good since it had R-Square value of 0.930 . Meaning, the variation proportion of job satisfaction variable explained by the independent variables was $93 \%$ and the remaining was explained by other independent variables. Table 2 below was an estimation of data regression variables influencing the employee performance.

Table 2: Employee Performance Regression Estimation

\begin{tabular}{|c|l|c|c|}
\hline No. & \multicolumn{1}{|c|}{ Variables } & Coefficient & p-value \\
\hline 1 & Constant & 9.590 & $0.000^{*}$ \\
\hline 2 & Organizational Culture (OC) & 0.156 & 0.048 \\
\hline 3 & Work Motivation (WM) & 0.310 & 0.001 \\
\hline 4 & Job Satisfaction (JS) & 0.532 & 0.000 \\
\hline
\end{tabular}

* Significant on level 5\%

From the output of data processing, the value of the $\mathrm{p}$-value variable obtained was 0.000 . Therefore, there was at least one variable that was not 0 , it could be concluded that simultaneously, the independent variables influenced the employee performance. Based on the data of table 3 above, an equation could be made as follows:

Employee Performance $(\mathrm{EP})=+0.156 \mathrm{OC}+0.310 \mathrm{WM}+0.532 \mathrm{JS}+0.265$

To clarify the basic concepts of path analysis in this research, the values above are included in the structural model as follows: 


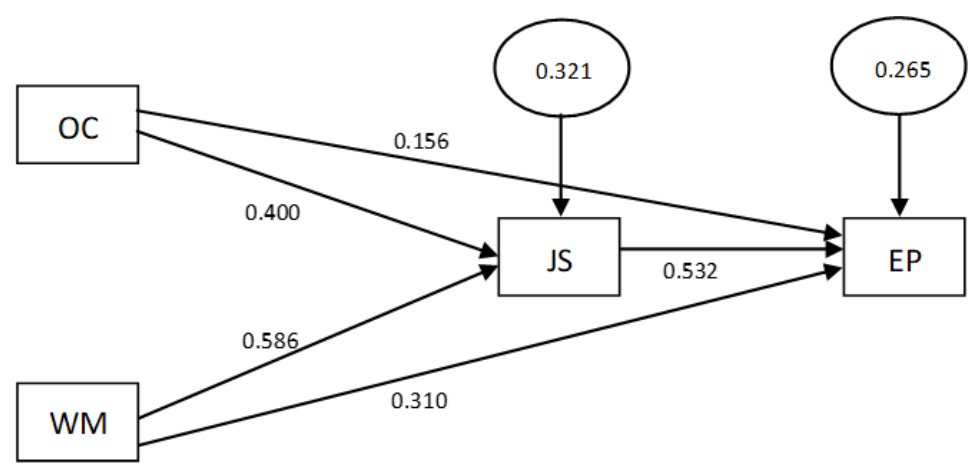

Figure 1

Causal Correlation OC, WM. JS towards EP

The indirect effect of OC through JS on EP could be determined by multiplying the beta value of OC towards JS with beta value of JS towards EP: $0.400 \times 0.532=0.213$. The total effect of OC towards EP was $0.156+0.213=0.395$. Because the indirect effect $(0.213)$ was greater than the direct effect $(0.156)$, OC through JS had a significant effect on employee performance (EP). Likewise, the indirect effect of WF through JS on EP could be determined by multiplying the beta value of OC towards JS with beta value of JS towards EP: $0.586 \mathrm{x}$ $532=0.312$. The effect of total WM on EP was $0.310+0.312=0.622$ because the indirect effect $(0.312)$ was higher than the direct effect (0.310), OC through JS had a significant effect on employee performance (EP).

Based on the statistical tests above, organizational culture had a significant effect on job satisfaction with a t-count $(5,104)$ higher than t-table $(2.000)$, p-value 0.000 , and a regression coefficient of 0.400 . Meaning, the better the value of organizational culture, the more job satisfaction of employees increased. Organizational culture is an integral part of the dynamics of organizational environment life. Organizational culture includes the behavior patterns, systems, and procedures applicable in the company. If the organizational culture is conducive and encourages the implementation of all works, the employees' job satisfaction will increase. Conversely, if organizational culture values such as togetherness, work methods, and relationships between superiors and subordinates are not harmonious, it will result in low job satisfaction. The results of this research are consistent with the theory used in this research, and support the results of previous studies such as the results of the studies carried out by Ouchi (1982), Kreitner \& Kinicki (2007), Kotter \& Heesket, 1997, and Sedarmayanti, 2017. It was also supported by the results of the studies carried out by Ilham (2018), Nair \& Sommerville (2017), Zhang \& Li (2013), Soetikno (2017), and Susetyo and Darmanto (2015).

Based on the statistical tests above, work motivation had a significant effect on job satisfaction with a tcount (7.491) higher than t-table (2.000), p-value 0.000, and a regression coefficient of 0.586. Meaning, the more motivated the employees in working, the higher their job satisfaction was. Work motivation played an important role in improving job satisfaction of the employees. High work motivation can foster a desire of working well, encourage seriousness of employees at work, encourage efforts to overcome feelings of dislike in solving problems that arise in carrying out tasks, so that the employees feel satisfaction in carrying out their duties. The results of this research are consistent with the theory used in this research, and support the results of previous studies carried out by Rees \& McBrain (2007), Robbins (2003), and Greenberg \& Baron (2003). It was also supported by the results of studies by Kadir and Mamalia (2017), Langi et al. (2015), Bajpai and Rajpol (2018), Sohail et al. (2014), Saleem et al. (2010), Cong and Van (2013), and Ali et al. (2016).

Although the effect of organizational culture on job satisfaction was low, the organizational culture had a significant effect on employee performance with a t-count (2.032) higher than t-table (2.000), p-value 0.048, and the regression coefficient of 0.156 . Meaning, the more intense the efforts in instilling the cultural values of the organization to the employees, the higher the employee job satisfaction was. A good organizational culture will sharpen the values, beliefs, and attitudes in the course of achieving good employee performance. A good organizational culture will foster employee emotional ties to the organization. Organizations can create a good and positive cultural climate by formulating values and rules, and by providing knowledge to customers. The formulation of values and rules should be understood and applied by employees towards the achievement of individual performance and organizational goals. The results of this research are consistent with the theory used in this research, and support the results of previous studies carried out by Rees \& McBrain (2007), Robbins (2003), and Greenberg \& Baron (2003). It is also supported by the results of studies by Langi et al. (2015), Mappamiring (2012), Bangun et al. (2018), Ali et al. (2016), Mubarok and Putra (2018), Cong and Van (2013) and Widyaningrung (2011).

Based on the results of the statistical tests above, motivation had a significant effect on employee performance with a t-count (3.382) higher than t-table (2.000), p-value 0.000 , and a regression coefficient of 0.310 . Meaning, the better and safer the work motivation level is, the increasingly higher the level of employee performance is. Fair work motivation encourages positively the employees to perform well. Work motivation in 
financial form plays an important role in directly meeting the needs of employees, especially the physiological needs. If the work motivation system is carried out fairly and competitively, it will encourage the employees to compete for the best performance. The results of this study is in accordance with the theory used for this study and is also supported by the results of the studies carried out by Bangun et al. (2018), Langi et al. (2015), Syauta et al. (2012), Miah, Md Murad (2018), Davoodalmousavi (2013), Kamau and Wanyoike (2019), Purnma (2013), Ahamed and Mahmood (2015).

Likewise, the results of statistical tests show that work satisfaction significantly influences employee performance with t-count (4.790) greater than t-table (2.000), p-value 0.000, and regression coefficient of 0.532. Meaning, the increasingly higher the job satisfaction, the increasingly higher the level of employee performance is. A high level of job satisfaction encourages the ability of employees to work well, without burden, without pressure, and working becomes fun. Employees who are satisfied both with the work environment, the attitude of superiors, as well as the work motivation system applied by the company, they will try to work optimally so that their performance improves well. The results of this study is in accordance with the theory used for this study and is also supported by the results of the studies carried out by Bangun et al. (2018), Langi et al. (2015), Syauta et al. (2012), Miah, Md Murad (2018), Davoodalmousavi (2013), Kamau and Wanyoike (2019), Purnama (2013), Ahamed and Mahmood (2015).

Organizational culture mediated by job satisfaction affects significantly the employee performance. It is indicated by the value of indirect influence higher (0.213) than the value of direct influence (0.156). Meaning, the position of job satisfaction as an intervening variable for organizational culture and employee performance strengthens direct influence. The role of organizational culture has a strategic position in realizing the organization's vision, mission and goals. Cultural values that are in accordance with the organization can encourage the implementation of activities well, that consequently, the employees' job satisfaction will increase and they work with better performance. The result of this research was in accordance with the hypothesis proposed in this research.

Work motivation mediated by job satisfaction affected significantly the employee performance. It is indicated by the value of indirect influence higher (0.312) than the value of direct influence $(0.310)$. Meaning, the position of job satisfaction as an intervening variable for work motivation and employee performance strengthened the direct influence. The effect of work motivation on performance was determined by job satisfaction. Employee performance would improve optimally when they are satisfied with the factors that encourage work motivation provided by the organization. Motivation for work given fairly would make employees satisfied and it ultimately affected the employees' performance. The result of this research was in accordance with the hypothesis proposed in this research.

\section{Conclusion}

In accordance with the purpose of this research, which was to test the effect of organizational culture, work motivation on job satisfaction and its impact on employee performance, the results of this research were formulated into the following several conclusions. First, organizational culture and work motivation had significant effect on work satisfaction. The better the organizational culture values are instilled and understood by the employees in work life, the increasingly higher the job satisfaction was. Meaning, the more motivated the employees in carrying out their duties, the higher their job satisfaction was. Second, organizational culture and work motivation had significant effect on employee performance. The better the organizational culture values are instilled and understood by the employees in work life, the increasingly higher the employee performance was. Meaning, the more motivated the employees in carrying out their duties, the higher the employee performance was.

Third, job satisfaction had a significant effect on employee performance. The more satisfied the employees were in carrying out their duties, the increasingly higher the employee performance was. Forth, work satisfaction was able to significantly mediate the indirect effect of organizational culture and work motivation on employee performance. The mediation significance of job satisfaction was able to directly support the indirect effect of organizational culture and work motivation on employee performance. Fifth, the strength values of dependent variable shown by the calculation results of the multiple correlation squared (R2) value of both job satisfaction and employee performance were significant.

From the results of this study it was revealed that organizational culture and work motivation factors had a significant effect on job satisfaction as well as employee performance. Also, job satisfaction had a significant effect on employee performance. As a dependent variable, employee performance had a higher coefficient than the job satisfaction variable. The results of this research provided a number of managerial implications in the managerial implication of governmental institution employees, viz. First, organizational culture was one of factors affected significantly the creation of job satisfaction and employee performance. Organizational culture contained the beliefs, values, and norms adopted and gives meaning to employees so that they felt job satisfaction and worked with good performance. Therefore, to make the organizational culture conducive in the 
course of realizing job satisfaction and employee performance, managers are required: (1) to master leadership styles able to be applied in a various work situations; (2) to apply rules that are clear and truly understood; (3) to have emotional maturity to deal with situations when the behavior and attitudes of others are not the same as ours; (4) to have the interaction ability having a major impact on success in influencing situations; and (5) to have the ambiguity tolerance, sensitivity to the others' feelings, and patient approach. Second, work motivation was one of factors affected significantly the creation of job satisfaction and employee performance. Therefore, managers could potentially improve the employee motivation by giving various efforts so that job satisfaction and employee performance would be better. The efforts could be in the form of remuneration improvement, supervision quality enhancement, communication pattern advancement, recognition and so on.

In connection with the benefits of research both for the development of science (theoretical) and for the management of the company (practical), the suggestions are as follows. First, with respect to the development of science, this research needs to be followed up with further researches, especially those aiming at reducing limitations or enriching this research. It relates to the use of basic theories and research instruments, increases the number of research samples, expands the area and segment of research, adds the variables, or uses different data analysis techniques. Second, with respect to governmental institution management, the institutional management should be evaluated periodically, so that job satisfaction is maintained and even increased. The evaluations carried out are mainly those relevant to organizational culture and work motivation.

\section{References}

Amstrong, Mickael \& Baron, Angela. 1998. Performance Management. London: Institute of Personal and Development

.2009. Amstrong's Handsbook of Human Resources Management. Practice $11^{\text {th }}$ Edition. United Kingdom: Kogan Page

Ahamed, Maruf \& Mahmood, Ramzan. 2015. Impact of Organizational Culture on Job Satisfaction: A Study on Bangalion Communication Ltd. Bangladesh: European Journal of Business and Management. Vol. 7 ISSN 2222-1905 (Page) ISSN 2222-2839 (Online)

Arifudin, Aldisa, et al. 2018. Pengaruh Pemberdayaan dan Budaya Organisasi terhadap Kepuasan Kerja Serta Dampaknya terhadap Kinerja Pegawai Dinas Perhubungan Kabupaten Merauke. HJABE Hasanuddin Journal of Applied Business and Entrepreneurship, Vol. 1

Ali, Amjad, Bin, Li Zhong, Piang, Huan Jian, \& Ali, Zulfiqar. 2016. The Impact of Motivation on The Employee Performance and Satisfaction in IT Park (Software House) Sector of Pashawar, Pakistan. International Journal of Academic Research in Business and Social Science. Vol. 6(9): ${ }^{*} 2222-6990$

Byars, Liyod L. \& Rue, Lesli W. 2008. Human Resources Management. New York: McGraw-Hill Irwin.

Bangun, Ramoon, Theresia Linda, Lahudin, A. H. \& Ranti, Gadih. 2018. The Influence of Culture, Job Satisfaction and Motivation on The Performance Lecture/Employees, Proceedings of the International Conference on Industrial Engineering and Operational Management. Bandung-Indonesia. March 6-8.

Bajpai, Vivek \& Rajpot, Sweksha. 2018. Effect of Employees Motivation on Job Satisfaction and Organizational Commitment at Balco, Global Journal of Engineering Science and Research Management, ISSN 2349-4505. May

Bahaudin, Taufik. 1999. Brainware Management: Generasi Kelima Manajemen Manusia. Jakarta: Penerbit PT. Elek Media Komputindo.

Chatab, Nevizond. 2007. Profil Budaya Organisasi: Mendiagnosis Budaya dan Merangsang Perubahannya. Bandung: Penerbit Alfabeta.

Campbell, J. P. 1990. Modeling The Performance Prediction Problem in Industrial and Organizational Psychology, in M. D. Dunnette \& L. M. Hough (Eds.) Handbook of Industrial and Organizational Psychology. Palo Alto, CA: Consulting Psychologists Press, Inc. pp. 687-732.

Cameron, S. Kim \& Quinn, E. Robert. 1999. Diagnosing and Changing Organizational Culture: Based on The Competing Values Framework. USA: Addeson-Hesley Publishing Company, Inc.

Corvellec, H. 1997. Stories of Achievement-Narrative Features of Organizational Performance. New Brunswick: NJ Transaction Publishing

Corvellec, H. 2001. For a Narrative Criticism of Organizational Performance. Conference Paper for New Directions in Organizational Performance. Newcastle, UK. March 28-29

Cong, Nhat Nguyen \& Van, Dung Nguyen. 2013. Effects of Motivation and Job Satisfaction on Employees' Performance at Petrovietnam Nghe a Construction Joints Stock Corporation (PVNC), International Journal of Business and Social Science. 4(6).

Colquitt, Jason A., Jeffrey, A., LePine \& Mechael, J. Wesson. 2012. Organizational Behavior. New York: McGraw-Hill

Davoodalmousavi, Seyyed Mutahareh. 2013. The Correlation Between Organizational Culture and Job Satisfaction of Employees in Biotechnology Production Companies. Pelagia Research Library. ISSN: 2248- 
9215. Coden (USA): EJEBAU

Dessler, Gary. 2013. Human Resources Management. Thirteenth Edition. USA: Pearson Global Edition.

Glinow, Von Ann Mary \& McShare L., Stephen. 2007. Organizational Behavior. McGraw-Hill International. $4^{\text {th }}$ New York, USA.

Gomez-Mejia, L. R., Tosi, H., \& Hinkin, T. 1987. Management, Control, Performance, and Executive Conversation. Academy of Management Journal, Vol. 30(1): 70

Guerra, Dave. 2009. Superperformance: A New Theory for Optimization, Performance Improvement. Vol. 47(5): 8-14

Greenberg, Jeld L. \& Baron, Robert A. 2003. Behavior Organizations. New Jersey: Prentice Hall

Gibson, James 1., Ivancevich, John M., Donnelly, James H. \& Konopaske, Robert. 2000. Organizations. New York: McGraw-Hill

Guey, F., Chanal, J., Ratelle, C. F., Marsh, H. W., Larose, S., \& Brovin, M. 2010. Intrinsic, Identified and Controlled Types of Motivation for School Subjects in Young Elementary School Children. British Journal of Educational Psychology. 80(40): 711-735

Hartijasti, Yanki. 2001. Hubungan Antara Budaya Organaisasi Dengan Kinerja Perusahaan. Jakarta: Program Pasca Sarjana Fakultas Psikologi UI (Postgraduate Program, Psychology Faculty, University of Indonesia

Ilham, Romi. 2018. The Impact of Organizational Culture and Leadership Style on Job Satisfaction and Employee Performance. Journal of Advanced Management Science. Vol 6(1).

Idris, M. 2013. The Influence of Organizational, Commitment, Work Motivation and Financial Compensation. Thesis. Jakarta: Pancasila University

Koentjaraningrat. 1982. Budaya Moralitas dan Pembangunan. Jakarta: Penerbit PT. Grameda

Kreitner, Robert \& Kinicki, Angelo. 2007. Organizational Behavior. New York, USA: McGraw-Hill International. $7^{\text {th }}$ Edition.

Kotler, J. P. \& Hesket, S. L. 1997. Corporate Culture and Performance. Indonesian Edition. Jakarta: PT. Prenhallindo Simon \& Schuster

Kadir, M. A. Habibi, \& Amalia, Lia. 2017. The Effect of Job Motivation, Compensation, Organizational Culture Towards Job Satisfaction and Employee Performance of The Ministry of Man Power. International Journal of Business and Management Invention. Vol. 6: 73-80, issued May 5.

Kamau \& Wanyoike. 2019. Corporate Culture and Organizational Performance: A Case of Mayfair Casino, Naerobi City County, Kenya. Global Journal of Commerce and Management Perspective

Kasali, Renaid. 2009. MYELIN Motivasi Intangibles Menjadi Kekuatan Perubahan. Jakarta: Gramedia Pustaka Utama.

Luthan, Fred. 2007. Organizational Behavior. McGraw-Hill International. $11^{\text {th }}$ Edition. New York, USA.

Langi, Stifan R., Saerang, David P. E. \& Worang, Frederik G. 2015. The Impact of Leadership Style, Work Motivation and Job Satisfaction on Employee Performance: Bank BNI Kawangkoan Branch. Jurnal Berkala Ilmiah Efisiensi. Vol. 15(05)

Lewin, K. \& Neuhauer, F. 1984. European Management Systems: Towards Unity Out of Cultural Diversity, McGraw-Hill

Meyer, M. W. \& Zucker, L. G. 1989. Permanently Failing Organizations. Newbury Park, California: Sage

Mathis, Robert L. \& Jackson, John H. 2002. Manajemen Sumber Daya Manusia. Indonesian Edition. Jakarta: Penerbit Salemba Empat.

Mubarok, Endang Saefuddin. 2017. Manajemen Sumber Daya Manusia: Pengantar Keunggulan Bersaing. Jakarta: In Media.

Mappamiring. 2015. Effect of Cultural Organization, Leadership and Motivation of Work on The Performance of Employees. International Journal Academic Research in Business and Social Sciences. Vol. 5(12). ISSN: 2222-6990

Miah, Md Murad. 2018. The Impact of Job Employee Job Satisfaction Toward Organizational Performance: A Study of Private Sector Employee in Kuching, East Malaysia. International Journal of Scientific and Research Publication. Vol. 8 Issued December 12

Mubarok, Endang Saefuddin \& Putra, Hidayatullah. 2018. The Influence of Training, Competence, and Motivation on Employees Performance of Workers Social Security Agency in Banten Province, Indonesia. Journal of Economics and Sustainable Development, ISSN 2222-1700 (Paper) ISSN 2222-2855 (Online). Vol. 9(4)

Maegginson, L. C., Mosley, D. C. \& Pietri, P. H. 1982. Management Concept and Applications. $4^{\text {th }}$ Edition. New York: Harper Collins.

Nair, Sree Leksmi Sreekumaran \& Sommerville, Steve. 2017. Impact of Organizational Culture on The Indian I.T. Workforce's Job Satisfaction and Stress: Qualitative Report from SMEs Operating Trivandum. MPRA Munich Personal Archive.

Ouchi, W. G. 1982. Theory Z: How American Business Can Meet The Japanese Challenge. Tokyo, Japan: 
Reading, Mass, Addition-Wesley Publishing

Priansa, Donni Juni. 2016. Perencanaan dan Pengembangan SDM. Bandung: Penerbit Alfabeta.

Prunama, Chamdan. 2013. Influence Analysis of Organizational Culture, Organizational Commitment and Satisfaction Organizational Citizenship Behavior (OCB) Toward Improved Organizational Performance. International Journal, Humanities and Technology. Vol. 3(3) May

Robbins, P. Stephen. 2005. Organizational Culture. USA: Pearson Prentice-Hall. Pearson Education International, $11^{\text {th }}$ Edition. New Jersey

Robbins, Stephen P. 2003. Perilaku Organisasi. Indonesian Edition. Jakarta: Penerbit PT. Index.

Robbins, Stephen P. 2006. Teori Organisasi: Struktur, Desain, dan Aplikasi, Indonesian Edition. Jakarta: Penerbit Arcan.

Rees, David \& McBrain, Ricard (eds). 2007. People Management: Challenges and Opportunities. Palgave Macmillan.

Subari, S. \& Riady, H. 2014. The Influence of Training, Competence, and Motivation toward Employee Performance as Moderated by Internal Communication, American Journal of Business and Management. 4(3): 133-145

Susanto, A. B. 1997. Budaya Perusahaan: Manajemen dan Persaingan Bisnis. Jakarta: PT. Alex Media Komputindo

Sedarmayanti. 2017. Perencanaan dan Pengembangan Sumber Daya Manusia: Untuk Meningkatkan Kompetensi, Kinerja, dan Produktivitas Kerja. Bandung: PT. RefikanAditama.

Sohail, Amir, Safdar, Robina, Saleem, Salma., Ansar, Samara., \& Azeem, M. 2014. Effect of Work Motivation and Organizational Commitment on Job Satisfaction: A Case of Education Industry in Pakistan. Global Journal of Management and Business Research: Administration and Management. Vol. 14(6) Ver. 1.0.

Soetikno, Yohannes Johny. 2017. The Influence of Work Environment and Organizational Culture on Work Satisfaction and Lectures Performance at The Schools of Management Information and Computer In Sulawesi. International Journal Science \& Technology Research. Vol. 6, Issued April 04.

Syauta, Jack Henry, Troena, Eka Afinan, Setiawan, Margono, \& Solimun. 2012. The Influence of Organizational Culture, Organizational Commitment to Job Satisfaction and Employee Performance. International Journal of Business and Management Invention. ISSN (online): 2319-8028, ISSN (Print) 2319-8018.

Suparjo \& Darmanto, Susetyo. 2015. Mediating Role of Jobs Satisfaction among Organizational Commitment, Organizational Culture and Citizenship Behavior in Central Java, Indonesia. Journal of Research in Marketing Vol. 4(1) February.

Sugiyono. 2002. Business Research Methods. Bandung: Penerbit Alfabeta

Sekaran, U. 2009. Research Methods for Business: A Skill Building Approach. New York: John Wiley and Son

Saleem, Rizwan, Mahmood, Azeem \& Mahmood, Asif. 2010. Efffect of Work Motivation on Job Satisfaction in Mobile Telecommunication Service Organizations of Pakistan. International Journal of Business and Management. Vol. 5(11), November.

Sempane, M. E., Rieger, H. S. \& Roodt, G. 2002. Job Satisfaction in Relation to Organizational Culture. South African of Industrial Psychology. 28(2): 23-30.

Vecchio, Robert P. 1995. Organizational Behavior. Florida: The Dryden Press

Vroom, V. J. 1964. Work and Motivation. New York: Willey.

Werther, B. William \& Davis, Keith. 1996. Human Resources and Personal Management. USA: Irwin/McGrawHill, Fifth Edition

Wibowo. 2008. Manajemen Kinerja. Jakarta: Penerbit PT. RajaGrafindo Persada.

2016. Manajemen Kinerja. Edisi Kleima, Jakarta: PT. RajaGrafindo Persada.

Widyaningrum, Mahmudah Eny. 2011. Influence of Motivation and Culture on Organizational Commitment and Performance of Employment of Medical Services. Academic Research International. ISSM 2223-9553. Vol. 1 issued on November 3.

Zhang, Xiaoxia, \& Li, Bingg. 2013. Organizational Culture and Employee Satisfaction: An Exploratory Study. International Journal Trade and Finance. Vol. 4(1), February. 